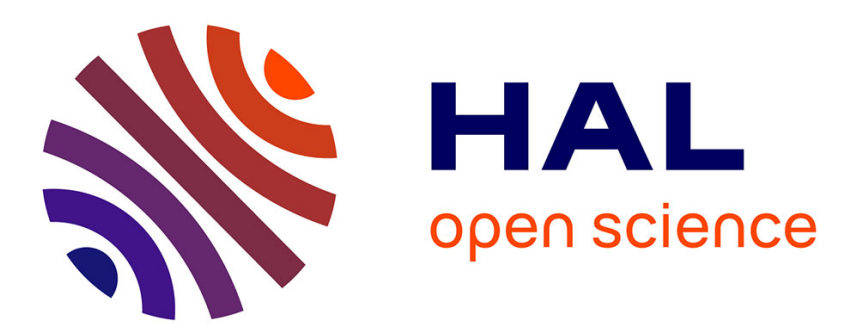

\title{
Partially Reversible Thermal-Induced Oxidation During a Dehydration Process in an H-bonded Supramolecular System
}

Sylvie Ferlay, Petra Hellwig, Mir Wais hosseini

\section{- To cite this version:}

Sylvie Ferlay, Petra Hellwig, Mir Wais hosseini. Partially Reversible Thermal-Induced Oxidation During a Dehydration Process in an H-bonded Supramolecular System. ChemPhysChem, 2018, 19 (23), pp.3219-3225. 10.1002/cphc.201800845 . hal-02300914

\section{HAL Id: hal-02300914 https://hal.science/hal-02300914}

Submitted on 26 Nov 2020

HAL is a multi-disciplinary open access archive for the deposit and dissemination of scientific research documents, whether they are published or not. The documents may come from teaching and research institutions in France or abroad, or from public or private research centers.
L'archive ouverte pluridisciplinaire HAL, est destinée au dépôt et à la diffusion de documents scientifiques de niveau recherche, publiés ou non, émanant des établissements d'enseignement et de recherche français ou étrangers, des laboratoires publics ou privés. 


\title{
Partially reversible thermal induced oxidation during a dehydration process in an $\mathrm{H}$-bonded supramolecular system
}

\author{
Sylvie Ferlay, ${ }^{*[a]}$ Petra Hellwig, ${ }^{*[b]}$ and Mir Wais Hosseini ${ }^{*[a]}$
}

\begin{abstract}
The thermal behaviour of a $\mathrm{H}$-bonded molecular network A based on $\left[\mathrm{Fe}^{\mathrm{ll}}(\mathrm{CN})_{6}\right]^{4-}$ anions and organic bisamidium cations $\mathbf{1}^{2+}$ was investigated. Heating was found to induce the partial oxidation of $\left[\mathrm{Fe}^{\prime \prime}(\mathrm{CN})_{6}\right]^{4-}$ into $\left[\mathrm{Fe}^{\prime \prime \prime}(\mathrm{CN})_{6}\right]^{3-}$, together with a thermochromic effect and also a loss of crystallinity was evidenced from mid and far FT-IR spectroscopic data, XRPD and DSC/TGA analysis. Rehydration also partially reversed the redox reaction and its colour, and after that, a mixture of $\mathbf{A}$ with amorphous phases was observed. FT-IR spectroscopy revealed that the oxidation of $\mathrm{Fe}(\mathrm{II})$ was accompanied by deprotonation of the cation.
\end{abstract}

Molecular networks involving hexacyanoferrate(II) or (III) have been intensively studied. They have been based either in hydrogen bonded, halogen bonded or coordination networks. The 3D well-known Prussian Blue family (coordination network) has been extensively described, together with its inherent magnetic, ${ }^{[1],[2],[3],[4]}$ electrode material, ${ }^{[5],[6],[7],[8]}$ porous ${ }^{[9]}$ properties and applications in the field of decontamination or molecular sieves, for example. ${ }^{[10]}$ Among the Prussian Blue analogues (PBA) involving hexacyanoferrate, Co/Fe heterometallics exhibit many intriguing phenomena including electron and charge transfer, ${ }^{[11],[12]}$ together with photomagnetism. ${ }^{[13]}$ Other 3D MnFe systems were reported, displaying also electron transfer phenomena. ${ }^{[14]}$ Charge transfer has been evidenced in Prussian Blue Analogs (PBA for Co/Fe species), induced by temperature

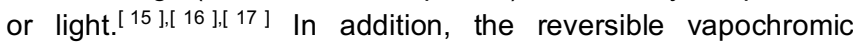
behaviour of PBA thin films has also been reported, , 18 evidencing the ability of hexacyanometallate, for oxidation or reduction.

Molecular networks based on halogen bonds involving cyanometallate have been scarcely described, ${ }^{[19}$ contrary to the cyanometallate embedded in hydrogen bonded networks. ${ }^{[2],[21],[22],[23]}$

The use of hexacyanoferrate(II) or (III) in hydrogen bonded networks has been already studied. This involves the use of directional ionic hydrogen bonding ${ }^{[24],[25],[26]}$ in combination with electrostatic interactions (Charge Assisted H-Bonding, CAHB), ${ }^{[27]}$ which allows the formation of robust molecular

[a] Prof. S. Ferlay, Prof. M. W. Hosseini

Molecular Tectonics Laboratory, University of Strasbourg, UMR UDS-CNRS 7140, Institut le Bel, 4, rue Blaise Pascal, F-67000 Strasbourg, France

ferlay@unistra.fr, hosseini@unistra.fr

[b] Prof. P. Hellwig

Laboratoire de Bioélectrochimie et Spectroscopie, University of Strasbourg, UMR UDS-CNRS 7140, Institut le Bel, 4, rue Blaise Pascal, F-67000 Strasbourg, France

hellwig@unistra.fr

Supporting information for this article is given via a link at the end of the document. networks with reliable recognition patterns. Robust molecular $\mathrm{H}$ bonded networks are candidates for applications in the field of proton conduction, sensing, separation or guest exchange. ${ }^{[28],[29],[30],[31]}$ Hexacyanoferrate(II) building blocks have been assembled with cationic $\mathrm{N}$ Hydrogen bond donors bisamidinium (example Figure 1 top), ${ }^{[32]}$ designed for the recognition of hydrogen bond acceptors like cyanometallate, leading to robust hydrogen bonded networks. ${ }^{[23],[33],[34]}$ Through this exploring and rationalised work, we have shown the possibility of mastering the connectivity between the chosen starting components, as well as the packing of the formed entities in the crystalline phase. Some of the reported compounds present luminescent properties using $\left[\mathrm{M}(\mathrm{CN})_{2}\right]^{-}$ $(\mathrm{M}=\mathrm{Ag}$ or $\mathrm{Au})$ anions. ${ }^{[35]}$ Concerning the porous properties, we have reported single-crystal-to-single-crystal transformation through dehydration process, leading to a series of 12 isostructral $\mathrm{H}$-bonded compounds using $\left[\mathrm{M}(\mathrm{CN})_{6}\right]^{3-}(\mathrm{M}=\mathrm{Fe}, \mathrm{Cr}$ or $\mathrm{Co}$ ) anions. ${ }^{[36]}$ Reversible de-solvatation processes have been reported frequently for hydrogen bonded networks. ${ }^{[37],[38],[39],[40]}$

We also reported the chemical reduction of a parent $\mathrm{H}$-bonded networks, involving the presence of $\left[\mathrm{Fe}^{\prime \prime \prime}(\mathrm{CN})_{6}\right]^{3-/} /\left[\mathrm{Fe}^{\prime \prime}(\mathrm{CN})_{6}\right]^{4-}$ anions and evidencing the intercalation of alkaline cations between the anionic $\mathrm{H}$-bonded layers during the reduction process $^{[41]}$ Redox processes in solid-state hydrogen bonded molecular networks, however, have been only scarcely studied in the solid state.

In this work, we report on the thermal dehydration and rehydration of an hydrogen bonded network (compound $\mathbf{A}$ ) involving $\left[\mathrm{Fe}^{\prime \prime}(\mathrm{CN})_{6}\right]^{4-}$ anions, revealing thermochromic properties associated with the partially reversible oxidation of the metallic anionic complexes into $\left[\mathrm{Fe}^{\mathrm{lI}}(\mathrm{CN})_{6}\right]^{3-}$ ions. The thermal induced dehydration process of $\mathbf{A}$ has been studied using differential thermal analysis (TGA and DSC) thermal powder XRay diffraction together with FT-IR. A spectroscopic evidence for the dehydration-rehydration process of this hydrogen bonded system is provided and a preliminarily mechanism is proposed.

\section{Results and Discussion}

The studied molecular $\mathrm{H}$-Bonded compound is based on the association of the $\left[\mathrm{Fe}^{\prime \prime}(\mathrm{CN})_{6}\right]^{4-}$ anion together with the bisamidinium cation $1^{2+}$ (Figure 1 middle); the resulting network is formed through the recognition of the pendant cyano together by the organic $\mathrm{H}$ bond donors. ${ }^{[42]}$ The structure has been already described and the network presents the following formula 12[Fe" $\left.(\mathrm{CN})_{6}\right] \cdot 8 \mathrm{H}_{2} \mathrm{O}$ (compound $\mathbf{A}$, Figure 1 middle); the structure consists of a 2D network formed by the interconnection of chains, arising from a $1 / 2$ anion/cation stoichiometry (triclinic, $\mathrm{P}-1$, $a=7.6538(2) \AA b=10.9276(3) \AA c=13.4639(3) \AA, \alpha=70.260(5)^{\circ}, \beta$ $=75.085(5)^{\circ}, \gamma=85.502(5)^{\circ}$ and $\left.V=1024.16(4) \AA^{3}\right)$. Eight water 
molecules (octamers, made from hexagons with two pendant $\mathrm{O}$ atoms) lying between the planes (see Figure 1 right) through $\mathrm{H}$ bonding with $\mathrm{C} \equiv \mathrm{N}$ moieties of the cyanometallate anions with O...N distances of in the 2.7616(2)-3.5781(2) $\AA$ range and O-O distances in the 2.7473(2)-2.8148(2) range, in order to form a $3 \mathrm{D} \mathrm{H}$-bonded network. The shortest $\mathrm{N}-\mathrm{O}$ distance is attributed to one pendant oxygen atom of the water octameric unit in interaction with $\mathrm{N}$ donor atom from amidinium species.

In this extended hydrogen bonded compound, the geometry around the metallic species is a deformed octahedron, as shown by bonds and angles around Fe (see Supporting Information).

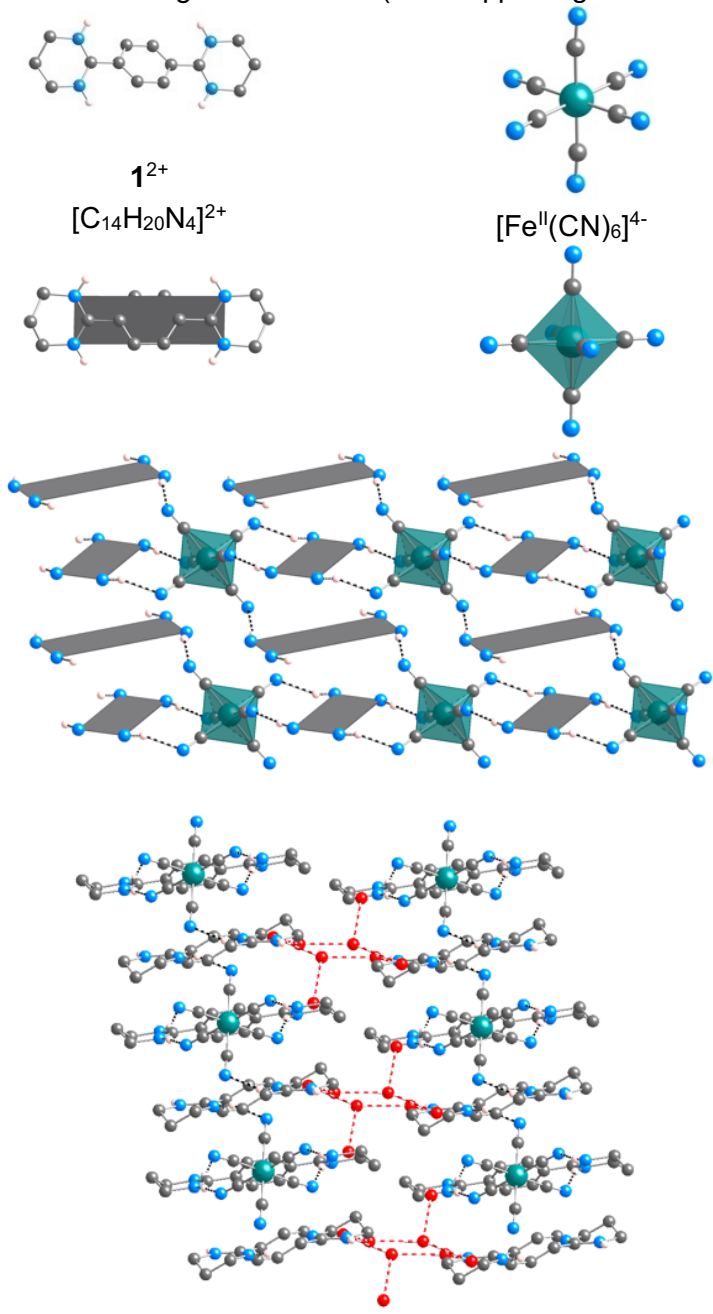

Figure 1. For 12-[Fe" $\left.^{\prime \prime}(\mathrm{CN})_{6}\right] \cdot 8 \mathrm{H}_{2} \mathrm{O}(\mathbf{A})$, (top) used building blocks for the formation of $\mathbf{A}$, together with their polyhedral representation (middle) polyhedral representation of the $2 \mathrm{D}$ hydrogen bonded network enhancing the recognition mode between the anions and cations (bottom) interconnection between the 2D H-bonded planes with octameric clusters of water molecules, leading to a $3 \mathrm{D} \mathrm{H}$-bonded system.

In order to understand the nature of the process encountered during dehydration/rehydration process of $\mathbf{A}$, several characterization techniques have been used and are presented below.

\section{Thermal behaviour}

The TGA trace of $\mathbf{A}$ between $25-300^{\circ} \mathrm{C}$ displays a decomposition of the compound from $280^{\circ} \mathrm{C}$ (see Figure S1 in Supporting Information).

When analysing the TGA traces at a heating rate of $2{ }^{\circ} \mathrm{C} / \mathrm{mn}$ in the $25-180{ }^{\circ} \mathrm{C}$ temperature range, it clearly indicates that 7 water molecules are evacuated at ca $100{ }^{\circ} \mathrm{C}$ whereas the remaining water molecule is released slowly between 100 and $180^{\circ} \mathrm{C}$ (see Figure S2 in Supporting Information).

This is an indication for the interaction energy between the network and the 8 water molecules, and it clearly depends on the nature of the water molecules. One water molecule, which might be attributed to the shortest $\mathrm{N}$...O distance between water molecules and $\mathrm{N}$ hydrogen bond acceptors (amidinium or $\mathrm{C} \equiv \mathrm{N}$ ), presents the strongest affinity with the network, and is released at higher temperatures.

The dehydration event was also studied by Differential Scanning Calorimetry (DSC) at the same heating rate, revealing a two-step process during the water release, between $60^{\circ} \mathrm{C}$ and $100^{\circ} \mathrm{C}$, as suggested by the TGA measurements, together with two other non-reversible processes occurring at $140^{\circ} \mathrm{C}$ and $170^{\circ} \mathrm{C}$ approximately (with a heating rate of $2^{\circ} \mathrm{C} / \mathrm{mn}$ ), as shown in Figure S3 in Supporting Information.

\section{Dehydration-rehydration and UV analysis}

The dehydration-hydration process of a polycrystalline sample of $\mathbf{A}$ was performed, revealing that the orange initial colour of $\mathbf{A}$, due to the presence of $\left[\mathrm{Fe}^{\prime \prime}(\mathrm{CN})_{6}\right]^{4-}$ units, was modified while heating: when heating at a rate of $2^{\circ} \mathrm{C} / \mathrm{mn}$, a brown colour appears between $110^{\circ} \mathrm{C}$ and $160^{\circ} \mathrm{C}$, then it turns to green from $180^{\circ} \mathrm{C}$ to $250^{\circ} \mathrm{C}$, prior to decomposition. It is important to note that when dehydrated, the compound is stable in air for several hours.

When the heated compounds, exhibiting a brown colour or green colour, are exposed to water, they reversibly return to their initial orange colour, as seen in the pictures presented in Figure 2.

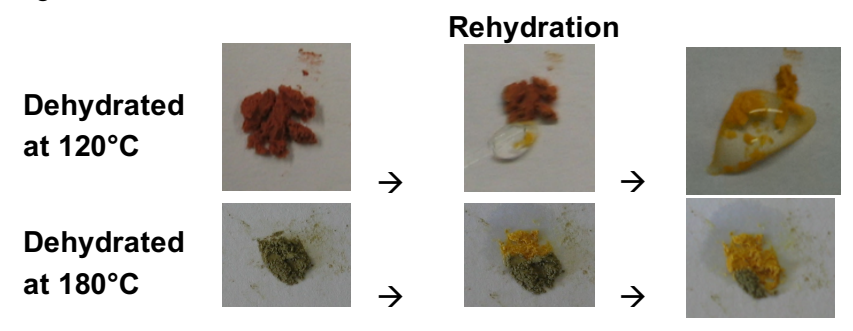

Figure 2. For $\mathbf{A}$, pictures showing the change of colour during the rehydration process for A dehydrated (top) at $120^{\circ} \mathrm{C}$ (brown starting colour) or (bottom) at $180^{\circ} \mathrm{C}$ (green starting colour) 
The observed colours are in accordance with the diffuse reflectance spectra displayed in Figure 3. It has been shown that the reflectance spectrum of the rehydrated compound (heated at $180^{\circ} \mathrm{C}$ (green) and then exposed to water) corresponds to the one of the freshly prepared compound $\mathbf{A}$.

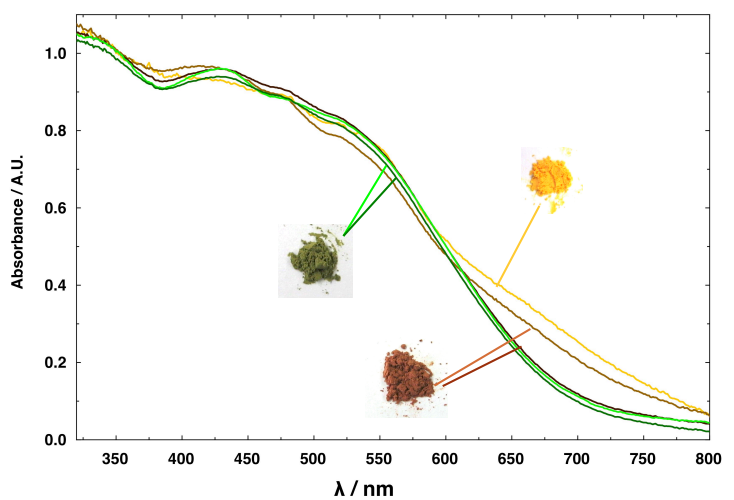

Figure 3. The UV-vis diffuse reflectance spectra of for 1-[Fe" $\left.(\mathrm{CN})_{6}\right]_{2} \cdot 8 \mathrm{H}_{2} \mathrm{O}$ as synthetized at RT (orange), heated at $110^{\circ} \mathrm{C}-150^{\circ} \mathrm{C}$ (brown) and heated above $160^{\circ} \mathrm{C}$ (green) showing the change of colour during the dehydration process

\section{Thermal XRPD}

Thermodiffractograms in the $25-200{ }^{\circ} \mathrm{C}$ temperature range are shown in Figure 4. The experimental diffractogram of the freshly prepared compound $\mathbf{A}$ is in accordance with the simulated diffractogram, derived from the structure obtained for A. The thermodifffractograms clearly evidenced a structural phase transition when dehydrating, above $90^{\circ} \mathrm{C}$ : a new crystallographic phase is appearing above this temperature. In addition, a broadening of the peaks is observed, linked to a loss of the crystallinity of $\mathbf{A}$ when heated. This confirmed the single crystal collapse, observed during the heating process. Unfortunately, due to the bad quality of the observed spectra, this phase could not further be identified.

Furthermore, after the rehydration of $\mathbf{A}$ heated at $200^{\circ} \mathrm{C}$, it evidently contains the initial phase with slightly different cell parameters (triclinic phase, P-1 space group of $\mathbf{A}$ ), but part of the crystallinity is lost, and the amount of amorphous phase present in the compound increases.

Contrary to the behaviour of the parent compound $\mathbf{1}_{3}$ $\left[\mathrm{Fe}^{\mathrm{III}}(\mathrm{CN})_{6}\right]_{2} \cdot 7 \mathrm{H}_{2} \mathrm{O}(2 \mathrm{D} \mathrm{H} \text {-bonded network })^{[36]}$ exhibiting a single crystal to single crystal transformation without change of colour, in the case of $\mathbf{A}$, the single-crystal-to-single-crystal transformation was not possible, due to the loss of crystallinity during the heating process.

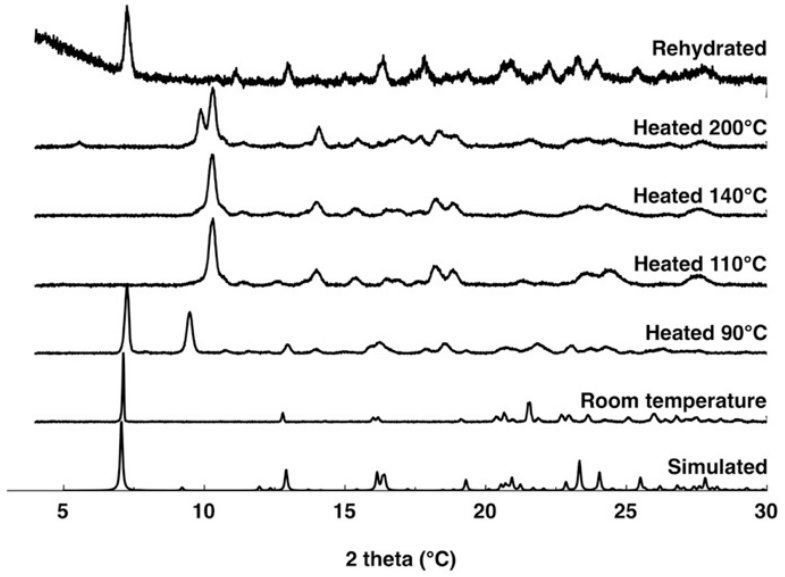

Figure 4. For microcrystalline A, XRPD thermodiffractograms obtained upon increasing the temperature in the $\mathrm{RT}-200{ }^{\circ} \mathrm{C}$ range. Only selected representative diffractograms are displayed (simulated from the XRD on single crystals, ${ }^{[42]}$ freshly prepared at room temperature, heated at $110^{\circ} \mathrm{C}$, at $160^{\circ} \mathrm{C}$, at $200^{\circ} \mathrm{C}$ and rehydrated).

\section{IR studies}

The frequency of the $\mathrm{C} \equiv \mathrm{N}$ stretching band in hexacyanoferrate, expected between 2100 and $1980 \mathrm{~cm}^{-1}$, is very sensitive to the oxidation state of iron and, in our case, its hydrogen bonding environment. The spectral signature of the $v(\mathrm{Fe}-\mathrm{CN})$ vibrational mode typically, expected between 600 and $300 \mathrm{~cm}^{-1}$, is also sensitive to the redox state of the metal. Figures $5 \mathrm{~A}$ and $\mathrm{B}(\mathrm{a}-\mathrm{e})$ show the IR spectra of polycrystalline $\mathbf{A}$ and their dehydrated analogues, heated at different temperatures, together with the rehydrated compound. At room temperature, signals for the $v(\mathrm{C} \equiv \mathrm{N})$ vibrational modes of $\left[\mathrm{Fe} \mathrm{C}^{\mathrm{II}}(\mathrm{CN})_{6}\right]^{4-}$ are seen at 2041,2032 and $2111 \mathrm{~cm}^{-1}$ in Figure $5 \mathrm{~A}$, a) and in table 1 . This is in line with the crystallographic data, where the deviation from the perfect octahedron is observed in $\left[\mathrm{Fe}^{\prime \prime}(\mathrm{CN})_{6}\right]^{4-}$ in $\mathbf{A}^{\left[{ }^{[42]}\right.}$ allowing three different vibrational modes. This is also in accordance with the signals found in the $\mathrm{K}_{4}\left[\mathrm{Fe}^{\prime \prime}(\mathrm{CN})_{6}\right]$ salt, as shown in table 1.

When heating $\mathbf{A}$, the observed $v(\mathrm{C} \equiv \mathrm{N})$ vibrational modes become broader and shift to higher wavenumber, revealing a weaker binding and a loss of the crystalline structure. A broad signal appears at $2108 \mathrm{~cm}^{-1}$ at $140^{\circ} \mathrm{C}$, that can be attributed to the oxidized $\left[\mathrm{Fe} \mathrm{e}^{\mathrm{II}}(\mathrm{CN})_{6}\right]^{3-}$ anion as the $v(\mathrm{C} \equiv \mathrm{N})$ values depend on the formal charge on the metal atom to which the $\mathrm{C} \equiv \mathrm{N}$ ligands are coordinated. This is in accordance with the values found for $\mathrm{K}_{3}\left[\mathrm{Fe}^{\prime \prime \prime}(\mathrm{CN})_{6}\right]$ salt, as shown in table 1 . The magnitude of shifting related to oxidation for $\left[\mathrm{Fe}^{1 / / 11}(\mathrm{CN})_{6}\right]^{4-/ 3-}$ can be expected to be around $50-100 \mathrm{~cm}^{-1}$ as seen for example for solid $\mathrm{K}_{3 / 4}\left[\mathrm{Fe}^{\| / / I I}(\mathrm{CN})_{6}\right]$ (see table 1). The shift is completely reversible when re-hydrating the compound. It is important to note, that even when $\mathbf{A}$ is heated to $200^{\circ} \mathrm{C}$, residual non-oxidized $\left[\mathrm{Fe}^{\prime \prime}(\mathrm{CN})_{6}\right]^{4-}$ anion is present. This is independent from the time of heating. Whereas $\mathbf{A}$ is dehydrated at $200^{\circ} \mathrm{C}$ and rehydrated 
with $\mathrm{H}_{2} \mathrm{O}$, it doesn't contain any $\left[\mathrm{Fe}^{\mathrm{II}}(\mathrm{CN})_{6}\right]^{3-}$ oxidised species, as seen from the IR data.

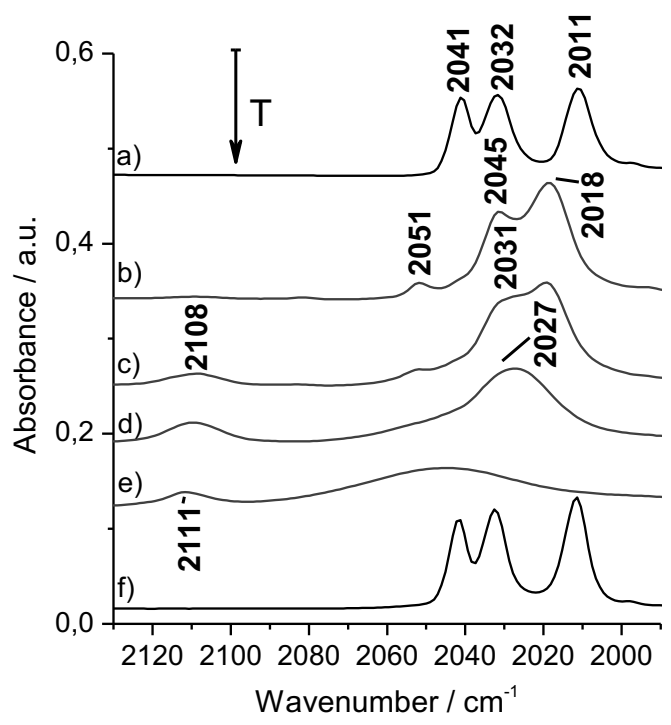

A

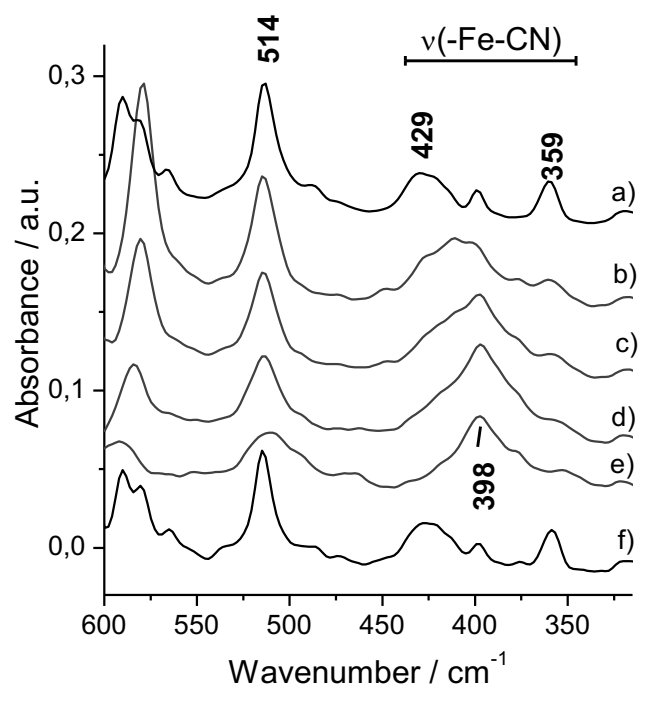

B

Figure 5. For compound $\mathbf{A}, \mathrm{MIR}$ and $\mathrm{FIR}$ absorbance spectra at room temperature (a), after heating to $100^{\circ} \mathrm{C}(\mathrm{b}), 140^{\circ} \mathrm{C}(\mathrm{c}), 160{ }^{\circ} \mathrm{C}(\mathrm{d}), 200^{\circ} \mathrm{C}$ (e) and the sample heated to $200^{\circ} \mathrm{C}$ after rehydration (f). A shows the spectral range specific for the $v(\mathrm{C} \equiv \mathrm{N})$ vibrational modes of the oxidized and reduced species, B the $v(\mathrm{Fe}-\mathrm{CN})$ vibrational mode.

\begin{tabular}{|c|c|c|}
\hline $\begin{array}{l}\text { Compound vs Tentative } \\
\text { assignments }^{43}\end{array}$ & $v(\mathrm{C} \equiv \mathrm{N}) / \mathrm{cm}^{-1}$ & $v(\mathrm{Fe}-\mathrm{CN}) / \mathrm{cm}^{-1}$ \\
\hline $\mathrm{K}_{4}\left[\mathrm{Fe}^{\prime \prime}(\mathrm{CN})_{6}\right]$ solid & 2040 & $585 / 414$ \\
\hline $\mathrm{K}_{3}\left[\mathrm{Fe}^{\prime \prime \prime}(\mathrm{CN})_{6}\right]$ solid & 2118 & $511 / 387$ \\
\hline A, freshly prepared (a) & $2041 / 2032 / 2011$ & $567 / 429 / 359$ \\
\hline A Heated at $100^{\circ} \mathrm{C}(\mathrm{b})$ & $2051 / 2045 / 2018$ & $429 / 398 / 359$ \\
\hline A Heated at $140^{\circ} \mathrm{C}(\mathrm{c})$ & $2031 / 2018 / 2108$ & 398 \\
\hline A Heated at $160^{\circ} \mathrm{C}(\mathrm{d})$ & 2027 (very broad)/ /2111 & 398 \\
\hline A Heated at $200^{\circ} \mathrm{C}(\mathrm{e})$ & 2054 (very broad)/ /2111 & 398 \\
\hline $\begin{array}{l}\text { A Heated at } 200^{\circ} \mathrm{C} \text { and } \\
\text { rehydrated } \mathrm{H}_{2} \mathrm{O}(\mathrm{f})\end{array}$ & $2041 / 2032 / 2011$ & $456 / 729 / 359$ \\
\hline
\end{tabular}

Table 1: Comparison of $v(\mathrm{C} \equiv \mathrm{N}) / \mathrm{cm}^{-1}$ and $v(\mathrm{Fe}-\mathrm{CN}) / \mathrm{cm}^{-1}$ for $\mathbf{A}$ and related compounds.

In the spectral region from 600 and $300 \mathrm{~cm}^{-1}$ region, vibrational modes from $v(\mathrm{Fe}-\mathrm{CN})$ but also from the ligand can be expected. for A. Signals at 567, 429 and $359 \mathrm{~cm}-1$ are found at positions close to the $v(\mathrm{Fe}-\mathrm{CN})$ vibrational modes of solid $\mathrm{K}_{4}\left[\mathrm{Fe}^{\prime \prime}(\mathrm{CN})_{6}\right]$ (see table 1 for all positions and assignments), in accordance with the data from XRD analysis. After heating $\mathbf{A}$, the signals decrease gradually and a broad feature can be seen at $398 \mathrm{~cm}^{-1}$. This mode includes contributions of $\left[\mathrm{Fe}^{\prime \prime}(\mathrm{CN})_{6}\right]^{4-}$ as well as contributions of $\left[\mathrm{Fe}^{\text {III }}(\mathrm{CN})_{6}\right]^{3-}$ with weakened ligand interaction, in line with the observation made in the MIR. The non-crystalline nature of the sample is confirmed below $200 \mathrm{~cm}^{-1}$, where the complex signal structure (lattice and collective modes as well as contributions from water) is replaced by a broad non specific band. ${ }^{[44]}$

From the analysis of the vibrations arising from the $\mathrm{Fe}-\mathrm{CN}$ vibrational modes in FIR and MIR spectral range, a partial reduction of $\mathrm{Fe}$ can be concluded. At the same time, a lower symmetry of the compound, the loss of crystallinity and a loss in binding strength are observed. This is in line with the XRPD data shown above

In order to analyse the reactivity and protonation state of the involved organic $\mathrm{H}$-bond donor $\mathbf{1}^{2+}$, the spectra in the MIR range between 1800 and $600 \mathrm{~cm}^{-1}$ were studied. This spectral range is characteristic for the organic ligand and, by subtracting different states, the changes in the molecular structure can be highlighted. Difference spectra of the isolated $\mathrm{H}$ bond donor ligands in the protonated $\left(1^{2+}-2 \mathrm{Cl}^{-}\right)$and deprotonated (1) state were subtracted, leading to the difference spectra characteristic for the deprotonation reaction. These data were compared to the difference spectra obtained by subtracting the spectra of freshly prepared $\mathbf{A}$ and $\mathbf{A}$ heated at $200^{\circ} \mathrm{C}$. Both difference spectra are shown in Figure 6. Overall, the difference spectra are highly comparable, revealing the deprotonation of the ligand during the heating process. Smaller differences can be attributed to the different number of water molecules present in the 
polycrystalline structures, and not to differences in the protonation state of the $\mathrm{H}$ bond donor in $\mathbf{A}$ heated at $200^{\circ} \mathrm{C}$.

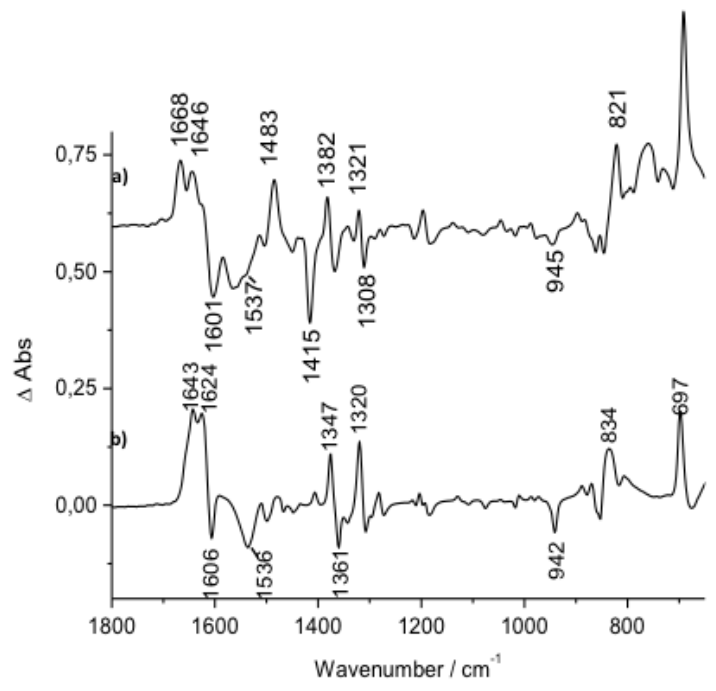

Figure 6. Infrared difference spectra obtained by subtracting the spectra in the middle infrared range between 1800 and $600 \mathrm{~cm}^{-1}$ of (1) and $\left(1^{2+}-2 \mathrm{Cl}\right)$ (a) and freshly prepared $\mathbf{A}$ (hydrated) to $\mathbf{A}$ heated at $200^{\circ} \mathrm{C}$ (b)

From the observed data, it can be concluded that the $\mathrm{H}$-bond donor ligand in A heated at $180^{\circ} \mathrm{C}$ is deprotonated. Unfortunately, the spectral data are not sensitive enough to evaluate the degree of protonation $\left(1^{2+}\right.$ and/or $1^{+}$and/or 1$)$ and the ratio between $1^{2+} / 1^{+} / 1$, for example.

\section{Discussion}

The change of colour for $\mathbf{A}$, when heated, corresponds to a partial change of the oxidation state of $\left[\mathrm{Fe}^{\prime \prime}(\mathrm{CN})_{6}\right]^{4-}$ converted into $\left[\mathrm{Fe}^{\prime \prime \prime}(\mathrm{CN})_{6}\right]^{3-}$, as shown by the $v(\mathrm{C} \equiv \mathrm{N})$ vibration of heated compound $\mathrm{A}$. The change in ratio of the $\left[\mathrm{Fe}^{\prime \prime \prime}(\mathrm{CN})_{6}\right]^{3-/} /\left[\mathrm{Fe}^{\prime \prime}(\mathrm{CN})_{6}\right]^{4-}$ seen in Figure $5 \mathrm{~A}$ confirms the thermal activation of the oxidation. These data are confirmed by EPR data for $\mathbf{A}$ heated at $180^{\circ} \mathrm{C}$, that evidently exhibits the presence of $\left[\mathrm{Fe}^{\mathrm{III}}(\mathrm{CN})_{6}\right]^{3-}$, (Figure S4, Supporting Information).

When rehydrated, the compound returns to its initial colour, thus evidently containing $\left[\mathrm{Fe}^{\prime \prime}(\mathrm{CN})_{6}\right]^{4-}$ cations. The presence of $\left[\mathrm{Fe} \mathrm{e}^{\prime \prime \prime}(\mathrm{CN})_{6}\right]^{3-}$ in rehydrated $\mathbf{A}$ was excluded.

In accordance with the XRPD and IR data the thermal oxidation can be corroborated with the loss of crystallinity. Spectra shown in Figure 5B clearly demonstrate that the environment of iron in dehydrated $\mathbf{A}$ presents a lower symmetry than the one of iron in freshly prepared $\mathbf{A}$. This loss of the symmetry evidenced by IR has already been documented. ${ }^{[45]}$ In addition, after rehydration the environment is still disturbed, which is also confirmed by XRPD measurements. This is in accordance with the rather low crystallinity of the rehydrated compound, containing the crystalline $\mathbf{A}$ phase and some amorphous phases.

Since there are still $\left[\mathrm{Fe}^{\prime \prime}(\mathrm{CN})_{6}\right]^{4-}$ anions in dehydrated $\mathbf{A}$ at $180^{\circ} \mathrm{C}$ and that the deprotonation of the dication $1^{2+}$ was observed, one can assume that its formula is the following: $\left(1_{2}\right.$ $\left.\mathrm{x}^{2+} \mathbf{1}^{+}\right)-\left(\left[\mathrm{Fe}^{\prime \prime}(\mathrm{CN})_{6}\right]^{4-}{ }_{1-\mathrm{x}}\right)\left(\left[\mathrm{Fe}^{\prime \prime \prime}(\mathrm{CN})_{6}\right]^{3-} \mathrm{x}\right)$ with a $\mathrm{x}$ value close, but not equal to 1 , as shown in Figure 7.

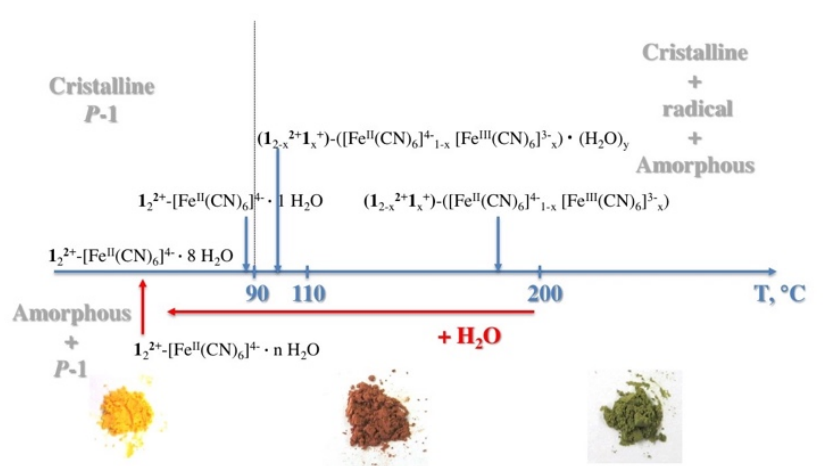

Figure 7. Proposed formula during the dehydration and rehydration process for $\mathbf{A}$

When heated from RT to $110^{\circ} \mathrm{C}$ (at a heating rate of $2^{\circ} \mathrm{C} / \mathrm{mn}$ ), A changes its formula from $\mathbf{1}_{2}{ }^{2+}-\left[\mathrm{Fe}^{\prime \prime}(\mathrm{CN})_{6}\right]^{4-} \cdot 8 \mathrm{H}_{2} \mathrm{O}$ to $\mathbf{1}_{2}{ }^{2+}-$ $\left[\mathrm{Fe}^{\prime \prime}(\mathrm{CN})_{6}\right]^{4-}$. $1 \mathrm{H}_{2} \mathrm{O}$, which corresponds to the loss of 7 water molecules. With $\mathrm{T}>110^{\circ} \mathrm{C}$, the thermal oxidation of $\left[\mathrm{Fe}^{\prime \prime}(\mathrm{CN})_{6}\right]^{4-}$ species into $\left[\mathrm{Fe}^{\mathrm{III}}(\mathrm{CN})_{6}\right]^{3-}$ begins, together with the corresponding deprotonation of the organic donor species, leading to a formula $\left(1_{2-x^{2+}} 1^{+}\right)-\left(\left[\mathrm{Fe}^{\prime \prime}(\mathrm{CN})_{6}\right]^{4-1-x}\right)\left(\left[\mathrm{Fe}^{\prime \prime \prime}(\mathrm{CN})_{6}\right]^{3-3-x} \cdot\right.$ y $\mathrm{H}_{2} \mathrm{O} \quad(0<x<1$ and $0<y<1)$. This process can be followed by DSC, which corresponds to the large peak between $120-140^{\circ} \mathrm{C}$. For $\mathrm{T}>$ $180^{\circ} \mathrm{C}$, the compound is fully dehydrated and the formula can be assumed to be $\left(\mathbf{1}_{2-x^{2+}} \mathbf{1}^{+}\right)-\left(\left[\mathrm{Fe}{ }^{\prime \prime}(\mathrm{CN})_{6}\right]^{4-}{ }_{1-x}\right)\left(\left[\mathrm{Fe}^{\prime \prime \prime}(\mathrm{CN})_{6}\right]^{3-} \mathrm{x}\right)$. In addition, after rehydration, the number of water molecules present in the rehydrated compound could not be determined precisely due to the presence of the amorphous phase.

The thermal oxidation/reduction of the $\left[\mathrm{Fe}^{\prime \prime}(\mathrm{CN})_{6}\right]^{4-}$ species involved in the hydrogen bonded was possible since the redox potential of $\left[\mathrm{Fe}^{\mathrm{III}}(\mathrm{CN})_{6}\right]^{3-} /\left[\mathrm{Fe}^{\mathrm{II}}(\mathrm{CN})_{6}\right]^{4-}$ is thermodynamically favourable. This has been reported with soluble species $\left(\mathrm{H}_{4} \mathrm{~L}_{2}\right)$ $\left[\mathrm{Fe}^{\prime \prime}(\mathrm{CN})_{6}\right] /\left(\mathrm{H}_{4} \mathrm{~L}_{2}\right)\left[\mathrm{Fe}^{\mathrm{III}}(\mathrm{CN})_{6}\right]^{+}$. [ $\left.{ }^{46}\right]$ Nethertheless, the thermal activation of oxidation has never been reported in Hydrogen bonded networks, but the light oxidation of $\mathrm{Fe}(\mathrm{II})$ species has been documented for coordination networks. ${ }^{[47],[48]}$

\section{Conclusions}

We reported on a hexacyanoferrate based hydrogen bonded system that presents some thermochromic effects, explained by a thermal induced oxidation: during the heating process, a partial conversion of $\left[\mathrm{Fe}^{\prime \prime}(\mathrm{CN})_{6}\right]^{4-}$ species into 
$\left[\mathrm{Fe}^{\mathrm{III}}(\mathrm{CN})_{6}\right]^{3}$ was determined by a combination of FT-IR, TGA, DSC and XRPD studies. This compound may find application as sensor, since the hydrogen bonded compound is robust and the dehydrated compound is also stable in air.

Electrochemical investigations in the solid state together with electronic densities calculations concerning the electron transfer between the involved species are under current investigation.

\section{Experimental Section}

Experimental Details. All the manipulations and characterization were performed in air on freshly prepared samples. The dehydrated compounds were stored under Ar atmosphere prior to characterization performed in air.

A $\left(1_{2}-\left[\mathrm{Fe}^{\prime \prime}(\mathrm{CN})_{6}\right] \cdot 8 \mathrm{H}_{2} \mathrm{O}\right.$ or $\left.\left[\mathrm{C}_{14} \mathrm{H}_{20} \mathrm{~N}_{4}\right]_{2}\left[\mathrm{Fe}^{\prime \prime}(\mathrm{CN})_{6}\right] \cdot 8 \mathrm{H}_{2} \mathrm{O}\right)$ has been obtained using the already reported procedure. ${ }^{[42]}$

IR

Infrared spectra of the polycrystalline samples have been obtained on a Vertex 70 FTIR spectrometer (Bruker, Karlsruhe, Germany). In the mid infrared (MIR; 4000 to $450 \mathrm{~cm}^{-1}$ ) a $\mathrm{KBr}$ beamsplitter and a MCT detector have been used. For studies in the far infrared (FIR; 600 to $50 \mathrm{~cm}^{-1}$ ) the system was changed to a Silicon beamsplitter and a FIR-dTGS detector. $50 \times 128$ scans have been averaged at a resolution of $2 \mathrm{~cm}^{-1}$ in the MIR and $5 \times 128$ scans at a resolution of $4 \mathrm{~cm}^{-1}$ in the FIR. No smoothing or other corrections are applied. Experiments have been performed with the dried powder on an ATR-FTIR cell (Harrick, USA) equipped with a Si crystal, as this system is suitable for both spectral ranges. Data were also measured on a Diamond crystal for comparison (data not shown). For rehydration, a small amount of water was added and drying allowed directly on the ATR crystal in the air.

\section{Thermogravimetric (TGA) Studies.}

TGA measurements have been performed on polycrystalline samples on Pyris 6 TGA Laboratory System (Perkin-Elmer), using a $\mathrm{N}_{2}$ flow of 20 $\mathrm{mL} / \mathrm{mn}$ and a heating rate of $2^{\circ} \mathrm{C} / \mathrm{mn}$.

\section{DSC Studies.}

DSC measurements have been performed on polycrystalline samples on a DSC Jade (Perkin-Elmer), using a $\mathrm{N}_{2}$ flow of $20 \mathrm{~mL} / \mathrm{mn}$ and a heat rate of $10{ }^{\circ} \mathrm{C} / \mathrm{mn}$ except for the case of crystals containing cobalt for which both heating rate of $2^{\circ} \mathrm{C} / \mathrm{mn}$ were imposed.

UV

UV-Vis reflectance was measured on a Perkin-Elmer Lambda $650 \mathrm{~S}$ spectrometer (spectra recorded in the reflection mode, using a $150 \mathrm{~mm}$ integrating sphere) with a resolution of $2 \mathrm{~nm}$ and a scanning rate of 200 $\mathrm{nm} \min ^{-1}$

\section{Powder diffraction studies (PXRD)}

Diagrams were collected on a Bruker D8 diffractometer using monochromatic $\mathrm{Cu}-\mathrm{K} \alpha$ radiation with a scanning range between 4 and $40^{\circ}$ using a scan step size of $8^{\circ} / \mathrm{mn}$.
As already demonstrated and currently admitted, for all compounds, discrepancies in intensity between the observed and simulated patterns are due to preferential orientations of the microcrystalline powders.

Variable temperature powder diffraction studies were performed under static air on the same diffractometer equipped with an Anton Parr HTK16 high temperature device. The dehydration-rehydration process has been studied in the $20-200-20{ }^{\circ} \mathrm{C}$ temperature range with $10^{\circ} \mathrm{C}$ steps for $\mathbf{A}$ The delay between consecutive acquisitions was $40 \mathrm{~min}$.

EPR

EPR spectra were recorded with an ESP 300E spectrometer (Bruker) operating at the $\mathrm{X}$-band and equipped with a standard TE102 rectangular cavity.

\section{Acknowledgements}

We thank the Universite de Strasbourg, the C.N.R.S., the International centre for Frontier Research in Chemistry (icFRC), the Labex CSC (ANR-10-LABX-0026 CSC) within the Investissement d'Avenir program ANR-10-IDEX-0002-02, the Institut Universitaire de France, the Ministère de l'Enseignement Supérieur et de la Recherche for financial support. Dr. S.Choua and N. Lebreton are warmly acknowledged for recoding the EPR spectra and fruitful discussions.

Keywords: Hexacyanoferrate $\cdot$ Hydrogen bonded network • thermal oxidation $\bullet I R$ spectroscopy $\bullet$ XRPD

[1] M. Verdaguer, A. Bleuzen, V. Marvaud, J. Vaissermann, M. Seuleiman, C. Desplanches , A. Scuiller, C. Train, R. Garde, G. Gelly, C Lomenech, I. Rosenman, P. Veillet, C. Cartier, F. Villain, Coord. Chem. Rev. 1999, 190-192, 1023-1047.

[2] M. Ohba, H. Okawa, Coord. Chem. Rev. 2000, 198, 313-328.

[3] X.-Y. Wang, C. Avendano, K. R. Dunbar, Chem. Soc. Rev. 2011, 40, 3213-3238.

[4] E. Coronado, G. M. Espallargas, Chem. Soc. Rev. 2013, 42, 1525-1539.

[5] C. Wessells, D., R. A. Huggins, Y. Cui, Nat. Commun. 2011, 2, 550.

[6] P. Canepa, G. S. Gautam, D. C. Hannah, R. Malik, M. Liu, K. G. Gallagher, K. A. Persson, G. Ceder, Chem. Rev. 2017, 117, 4287-4341.

[7] A. Paolella, C. Faure, V. Timoshevskii, S. Marras, G. Bertoni, A. Guerfi, A. Vijh, M. Armande, K. Zaghib, J. Mater. Chem. A, 2017, 5, 1891918932.

[8] J. Qian, C. Wu, Y. Cao, Z. Ma, Y Huang, X. Ai, H. Yang, Adv. Energy Mater., 2018, 8, 1702619.

[9] L. J. Murray, M. Dincă, J. R. Long, Chem. Soc. Rev. 2009, 38, 12941314.

[10] D. Parajuli, A. Takahashi, H. Noguchi, A. Kitajima, H. Tanaka, M Takasaki, K. Yoshino, T. Kawamoto, Chem. Eng. J. 2016, 283, 13221328.

[11] O. Sato, T. lyoda, A. Fujishima, K Hashimoto, Science, 1996, 272, 704-705;

[12] A. Bleuzen, C. Lomenech, V. Escax, F. Villain, F. Varret, C. Cartier dit Moulin, M. Verdaguer, J. Am. Chem. Soc., 2000, 122, 6648-6652

[13] O. Sato, T. Iyoda, A. Fujishima, K. Hashimoto, Science, 1996, 272, 704-705. 
[14] H. Tokoro, S.-i. Ohkoshi, T. Matsuda, K. Hashimoto, Inorg. Chem., 2004, 43, 5231-5236.

[15] M. C. Navarro, E. V. Pannunzio-Miner, S. Pagola, M. I. Gómeza, R. E. Carbonio, J. Solid. St. Chem., 2005, 178, 847-854.

[16] L. Reguera, E. Reguera, J. Balmaseda, J. Rodriguez-Hernandez, H. Yee-Madeira, J. Porous Mater., 2008, 15, 719-729.

[17] Z. Trávníček, R. Zbořil, M. Matiková-Mal'arová, B. Drahoš, J. Černák, Chem. Cent. J., 2013, 7-28.

[18] Hu-Y. Tang, Z. Chu, C-P. Li, X-M. Ren, C. Xue, W. Jin, Dalton Trans., 2016, 10249-10255

[19] J. E. Ormond-Prout, P. Smart, L. Brammer, Cryst. Growth Des., 2012, 12, 205-216.

[20] P. V. Bernhardt, G. A. Lawrance, B. W. Skelton, A. H. White, Austr. J. Chem., 1989, 42, 1035-1043.

[21] A. Hazra, K. L. Gurunatha, T. K. Maji, Cryst. Growth Des. 2013, 13, 4824-4836.

[22] I. Cvrtila, V. Stilinovic, Cryst. Growth Des. 2017, 17, 6793-6800.

[23] S. Ferlay, M. W. Hosseini, Eds. P. Samorì and F. Cacialli, Wiley-VCH, 2011.

[24] M. C. Etter, Acc. Chem. Res., 1990, 23, 120-126.

[25] G. R. Desiraju, Angew. Chem. Int. Ed., 1995, 34, 2311-2327.

[26] M. W. Hosseini, CrystEngComm., 2004, 6, 318-322.

[27] M. D. Ward, Chem. Commun., 2005, 5838-5842.

[28] K. T. Holman, A. M. Pivovar, M. D. Ward, Science, 2001, 294, 19071911.

[29] O. Saied, T. Maris, J. D. Wuest, J. Am. Chem. Soc. 2003, 125, 1495614957.

[30] C.-L. Chen, A. M. Beatty, J. Am. Chem. Soc., 2008, 130, 17222-17223.

[31] G. K. H. Shimizu, R. Vaidhyanathan, J. M. Taylor, Chem. Soc. Rev. 2009, 38, 1430-1449.

[32] M. W. Hosseini, Coord. Chem. Rev. 2003, 240, 157-166.
[33] S. Ferlay, O. Félix, M. W. Hosseini, J.-M. Planeix, N. Kyritsakas, Chem Commun., 2002, 702-703

[34] P. Dechambenoit, S. Ferlay, M. W. Hosseini, J.-M. Planeix, N. Kyritsakas, New. J. Chem., 2006, 30, 1403-1410.

[35] a) C. Parachiv, S. Ferlay, M. W. Hosseini, V. Bulach, J.-M. Planeix, Chem. Commun., 2004, 2270-2271; b) P. Dechambenoit, S. Ferlay, N. Kyritsakas, M. W. Hosseini, CrystEngComm, 2011, 13, 1922-1930.

[36] P. Dechambenoit, S. Ferlay, N. Kyritsakas, M. W. Hosseini, J. Am. Chem. Soc., 2008, 130, 17106-17113.

[37] C. J. Kepert, D. Hesek, P. D. Beer, M. J. Rosseinsky, Angew. Chem. Int. Ed., 1998, 37, 3158-3160.

[38] S. A. Dalrymple, G. K. H. Shimizu, J. Am. Chem. Soc., 2007, 129, 12114-12116

[39] Ji-J. Jiang, L. Li, M-H. Lan, M. Pan, A. Eichhöfer, D. Fenske, C-Y. Su, Chem. Eur. J. 2010, 16, 1841-1848.

[40] G. A. Hogan, N. P. Rath, A. M. Beatty, Cryst. Growth Des., 2011, 11, 3740-3743.

[41] P. Dechambenoit, S. Ferlay, N. Kyritsakas, M. W. Hosseini, Chem Commun., 2009, 6798-6800

[42] S. Ferlay, V. Bulach, O. Felix, M. W. Hosseini, J.-M. Planeix, N Kyritsakas, CrystEngComm, 2002, 4, 447-453.

[43] K. Nakamoto, Infrared and Raman Spectra of Inorganic and Coordination Compounds, Wiley, New York, 1963

[44] Y. El Khoury, P. Hellwig, Chem. Commun., 2017, 53, 8389-8399.

[45] P. M. A. Sherwood, Vibrational Spectroscopy of Solids, Cambridge University Press, Cambridge, 1972.

[46] A. Bianchi, M. Micheloni, P. Orioli, P. Paoletti, Inorg. Chim. Acta 1988, 146, 153-159.

[47] S. Decurtins, H. W. Schmalle, P. Schneuwly, J. Ensling, P. Gutlicht, J. Am. Chem. Soc.,1994,116, 9521-9528.

[48] O. Sato, T. lyoda, A. Fujishima, K. Hashimoto, Science, 1996, 272, 704-705. 


\section{Entry for the Table of Contents}

\section{ARTICLE}

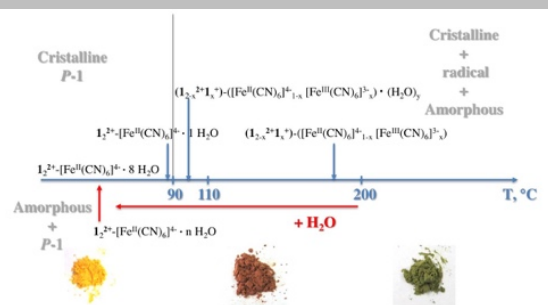

Sylvie Ferlay, ${ }^{*}$ Petra Hellwig, ${ }^{*}$ and Mir Wais Hosseini*

Page No. - Page No.

Partially reversible thermal induced oxidation during Dehydration process

in an $\mathrm{H}$-bonded supramolecular

system

The thermal behaviour of a $\mathrm{H}$-bonded molecular network $\mathbf{A}$ including $\left[\mathrm{Fe}^{\prime \prime}(\mathrm{CN})_{6}\right]^{4-}$ anions and organic cations $1^{2+}$ was investigated: a thermal partial oxidation of $\left[\mathrm{Fe}^{\prime \prime}(\mathrm{CN})_{6}\right]^{4-}$ into $\left[\mathrm{Fe}^{\prime \prime \prime}(\mathrm{CN})_{6}\right]^{3-}$ was evidenced from $\mathrm{FT}-\mathrm{IR}$ spectroscopic data complementary to XRPD, DSC/TGA analysis. This was accompanied by the formation of amorphous phases. The reduction of dehydrated $\mathbf{A}$ could be observed through the rehydration. 